\title{
A Survey of the Criteria Used by Commercial Banks in Kenya to Determine Employees to Retrench
}

\author{
Mercy Gacheri Munjuri \\ Department of Marketing and Management \\ The Catholic University of Eastern Africa \\ P.O Box 62157-00200, Nairobi, Kenya \\ E-mail: mgacheri@cuea.edu
}

Received: February 11, $2011 \quad$ Accepted: March 14, $2011 \quad$ doi:10.5430/ijba.v2n2p57

\begin{abstract}
The purpose of this paper was to establish the criteria used by commercial banks in Kenya to determine employees to retrench. The findings of the study suggest that commercial banks use seniority (Last-In-First-Out), employees' individual productivity, misconduct, incapability, early retirement programs, First-In-First-Out (FIFO) and employee obsolescence as criteria for determining employees to retrench. The criterion that is most popularly used is assessment of employees' individual productivity. Misconduct as a criterion for retrenchment is also popular and some of the behaviors that banks consider as misconduct include fraud, insubordination, regular unauthorized absenteeism, financial mismanagement, leaking out confidential information among others. Early retirement programs are also used to a moderate extent. Last in-First out (LIFO) is used to a moderate extent while incapability as a criterion is used to a less extent. It was also found that all banks use the same criteria despite their age, ownership and size.
\end{abstract}

Keywords: Retrenchment, Criteria, Commercial banks

\section{Introduction}

\subsection{Background of the study}

During the last two decades, retrenchment has become the strategy favoured by many companies attempting to cope with fundamental structural changes in the world economy. This trend is set to continue with more companies planning to retrench over the next few years.

Makawatsakul and Kleiner (2003) observe that for several years, there has been a strong tendency to adopt a downsizing strategy to deal with the economic pressures in the environment. Once seen as a short-term measure, downsizing has become the way to increase profitability. Of course, there are many anticipated benefits of downsizing, in terms of the economic level and increased operational efficiency of the organisation. It can increase productivity, the value of the companies' shares

and the profits by reducing the number of employees per unit. However, the hidden costs of this strategy are enormous and, more often than not, underestimated. In fact, they often eliminate all of the anticipated benefits. Unfortunately, massive downsizing very often seems to generate more problems than it solves, and only rarely does it achieve its original financial objectives.

Downsizing remains a multifaceted business phenomenon. While the body of literature is extensive and many valuable lessons have been learned over the past 30 years, the reactive and strategic practice of downsizing has continued unabated despite its dubious track record. Downsizing is probably also one of the most misunderstood and misinterpreted contemporary phenomena. Thus, a greater depth of understanding is required in order to establish a meaningful dialogue between businesses and academic communities (Gandolfi, 2009).

The 1960's had limitless possibilities of growth and expansion (Burke and Cooper, 2000). This was followed by a period of industrial strife, conflict and retrenchment in the 1970s. After the turmoil of the 1970's then came the "enterprise" culture of the 1980's. This was a decade of privatization, statutory constraints on industrial relations, mergers and acquisitions, strategic alliances, joint ventures, process re-engineering and the like transforming the workplaces into free market, hot house cultures (Burke and Cooper, 2000). 
Since the 1980s the business environment has witnessed an era of continual and dramatic change triggered primarily by global competitive pressures, enhancements in technology and a demanding customer-driven market (Ulrich, 1998). Large and bureaucratic organizations are no longer sustainable. Lean and fit, smaller and responsive organizations (Armstrong, 2001) seem to be preferred features of organization design. In order to achieve these ends, retrenchment has become and will continue to be a commonly applied technique (Sahdev et al., 1999).

The last two decades have also witnessed liberalization which has led to stiff competition in many sectors of the economy and has made firms change by taking certain actions in order to survive. One of these activities is retrenchment which is sometimes referred to as rightsizing. The Kenya business environment has been undergoing drastic changes for sometime now. Some of these changes include the accelerated implementation of economic reforms by the government, the liberalization of the economy, discontinuation of price controls, privatization and partial commercialization of the public sector and increased competition. In this changing environment, organizations have to constantly adapt their activities and internal configurations to reflect the new external realities. During the past year, the effects of economic recession forced companies to make hard decisions about their human capital investments as they worked to contain costs and maintain competitiveness. The most important asset to any organization is the human resources (Halcrow, 1997). People are the most common element in every organization and they can be used to further an organization's competitive advantage (Decenzo, 1998). However, when a cost reduction programme is implemented in any company, the first casualty is the human capital investment like cutting back benefits, staff retrenchment, freezing or cutting salary increases and cutting or freezing development programmes like training.

As Noer (1995) notes, organizations from public to private to non-profit making have "embarked on a frenzy of staff retrenchment". In his outstanding study, a major contribution to business literature, the author maintains that staff retrenchment has eroded the trust between employees and employers and have created a managerial paradigm. "Organizations that once saw people as assets to be nurtured and developed began to view those same people as costs to be cut". Noer(1995) in his publication entitled "Job Seeking" notes, while those who are dismissed are usually offered counseling services, those who remain are left to cope with anxiety and distress and the dismantled corporation, a process Noer terms as "lay off survivor syndrome". For the emerging and surviving organizations to sustain their existence and remain competitive, they have to properly manage the cost, while taking keen attention of the approach and effects of retrenchment on the company and the survivors of a layoff.

Retrenchment strategy has been adopted by many organizations as a way to deal with the economic pressures from the environment. This was first witnessed in the private sector, but has now spread to all levels of the government. The private organizations that adopted this strategy in Kenya include East African Breweries, Barclays Bank, East African industries, Bata Shoe Company, Shell BP, Agip, Coca cola company, Nestle (K) Ltd, Glaxowelcome (K) Ltd amongst others. The parastatals that have undertaken retrenchment include Kenya Airways, Kenya Tea Development Agency, Kenya Commercial Bank and National Bank of Kenya. In the civil service, various ministries have been reducing their staff since 1994 in an effort to reduce costs and increase efficiency.

Criteria for retrenchment must not be on grounds of race or sex. It must not be because of the employee's proposed or actual union membership or activities or because of union non-membership. Such aspects as skills and qualifications, standards of work, aptitude and attendance and disciplinary record may be considered alongside the traditional factor of length of employment. Some recognition of length of employment is likely to be regarded as reasonable criterion, but so too would be its tempering with business requirements such as the need to keep employees with particular skills, good records or flexible attitudes.

An employer must be able to defend the criteria chosen and the manner of application (Lewis, 1992).

Janse (2002) notes that if no previously agreed upon selection is available, fair, objective and non-discriminatory criteria must be used. The approach here must be that LIFO (Last in First out) should be the main criteria and where deviations from LIFO is contemplated in terms of skills retention, experience etc. a very thorough, detailed and bona fide motivation has to be provided. This issue must be handled carefully as it is often the cause of greatly emotional and subjective conflicts.

A common ground for complaint of unfair dismissal is unfair selection, therefore employers must take great care with the selection process. If there is no agreed procedure, employers must establish and be consistent in applying the criteria they will use to select employees for retrenchment. While "last in, first out", or length of service, is a well established method of selecting employees to be retrenched, it is not acceptable as the sole criterion. Further, it may not meet the employer's needs, and employers may wish to add criterion such as performance to the selection methods. Whatever the criteria, employers must be able to demonstrate that those criteria are fair and have been fairly and objectively applied, and that they have avoided giving unfair bias to specific criteria (www.ebc.com.au). 


\subsubsection{The banking sector in Kenya}

It is noted in the Central Bank of Kenya Supervision Annual Report (2001) that the banking system remained stable during the year 2001 and recorded remarkable increase in levels of profitability. Aggregate net profits before tax rose from Ksh. 2.8 billion in 2000 to Ksh. 8.9 billion in 2001. The overall audited performance of the banking sector measured in terms of capital adequacy, asset quality, liquidity and earnings remained fair, based on the Central Bank's internal rating system. The sector however, has continued to be faced with a number of challenges. These include reduced business activity arising from slow down in economic growth, and attempts made during the year aim at re-introducing interest rate controls. The stock of non-performing loans still poses a major challenge. The total number of banking institutions decreased by 5 during the year 2001, as a result of liquidations and mergers. The increasingly advanced levels of information technology embraced by banks have had a positive impact in the sector, though this has led to a massive reduction in the workforce. The new and dynamic information systems adopted by most banks have enabled them to process data faster and efficiently. This, coupled with increased use of Automated Teller Machines (ATMs) and on-line banking, has freed bank staff from the mundane manual processing tasks. In recent years, a number of mergers and acquisitions have taken place in the banking sector. Some of the mergers have been triggered by the need to meet the increasing minimum core capital requirements, and also to enhance institutions' market share in the highly competitive local banking environment through the resulting synergies. Over the last few years, there has been a tendency by some banks to reduce the number of their branches. This has in most cases been done with the objective of cutting down costs through staff reduction and to offer quality services to customers. There has been a change in assets composition due to harsh economic conditions that have led to the closure of a number of businesses and low effective demand for bank credit at both personal and corporate level.

\subsubsection{Retrenchment among commercial banks in Kenya}

The current economic down turn has continued to impact negatively on all businesses in the economy culminating in an unprecedented erosion of revenue margins whilst operational and administrative costs have tended to remain relatively high. The banking sector has not been an exception to this. All endeavours have been made to address these issues and measures have been implemented by banks with a view to achieving optimum results for all the stakeholders and to maintaining the banks market share. Such measures include investing enormous resources in information technology through which the banking halls have began to be decongested, rationalizing the banks branch network and in the process closing unprofitable units in an effort to reduce operating costs and outsourcing non-core services such as internal security services and computer transport in an effort to control administrative costs. Maintenance of these services has been costly to banks. The above measures have led to some changes in the level, type and quality of the banks current and future manpower requirements. In order that the banks can be able to meet new and emerging market challenges and thus remain competitive, it has become inevitable to gradually reduce the work force with the aim of improving productivity (Central Bank of Kenya, 2001).

An interview with the Human resource Manager of Kenya Commercial Bank was held on June 16th 2004 and he said, "The bank has introduced an early retirement scheme which will be implemented in phases and will take cognisance of the banks immediate, short-term and long-term manpower needs. The first phase will affect drivers, messengers and internal security staff whose functions have been taken over through outsourcing. Subsequent phases of the scheme to be advised will affect the other categories of staff and will be as a result of the recent automation of certain aspects of branch operations, discontinuation of encashing third party cheques, staff empowerment, improved systems among others. The rationale for retrenchment targeted people who have been performing poorly, outstanding disciplinary cases and medical cases among others. Kenya Commercial Bank reduced its work force from 4300 to 2700 workers and this was done between 1999 and 2004. The bank reduced its operation from 135 to 113 outlets."

The banking sector in Kenya comprises banks that are locally owned, foreign owned, joint ventures etc. Different banks started their operations at different times and they also differ in size. Banks are classified into small, medium, and large according to the value of assets owned by each. Banks may use certain criteria of retrenchment depending on their age, size and ownership.

\subsection{Statement of the problem}

The literature reviewed in the background indicates that virtually every type of organization faces an economic environment of continuous and accelerating change. An increasingly common response by organizations to this new economic environment is to engage in some form of restructuring which mainly includes retrenchment. Staff retrenchment practices are becoming common among firms and the companies that initiate them report varying effects ranging from short term gain, long term competitiveness and on the other hand, poor image and declining profitability. The effects are both on the organization and the employees. Retrenchment has become a common occurrence in today's 
business world. The decision to retrench is made for strategic and financial reasons. The expectation is that reduction in costs will lead to positive impact on the bottom line and will ultimately be reflected in improved profitability and productivity. If retrenchment is not well handled, the problems it was designed to correct may intensify due to its impact on the loyalty and attitudes of the survivors.

Some studies have been done on various aspects of retrenchment, for example: The nature of responses of survivors to downsizing by Moi (2002); A survey of factors that influence the attitudes of survivors of downsizing towards management and job security in the banking sector by Mwangi (2002); The problems experienced by organizations in managing the survivors of downsizing by Karimi (2002); A survey of the practices of staff downsizing among the major oil firms in Kenya by Guyo (2003). None of the studies has considered the criteria used by commercial banks in identifying employees to retrench, yet this is a crucial area in making retrenchment decisions.

It is becoming increasingly difficult for commercial banks to cut down the size of their workforce. There are a number of factors curtailing this freedom ranging from threat of discrimination suits, lack of evidence that dismissal is impartial and performance-related, a set of constraints, provided by the labour contract in unionized firms, legislation that would prohibit employers from firing workers except for just cause among others. A study by Mwangi (2002) on factors that influence the attitudes of survivors of downsizing towards management and job security in the banking sector, found that bank employees had a relatively low trust of the management's decisions and actions in the retrenchment process. They had a relatively strong feeling that there was injustice in the process. Usually, commercial banks are faced with the challenge of determining who to let go. The retrenchment exercise should not be seen as targeting certain individual or group of individuals but should follow certain criteria that are deemed to be objective. Yet, no systematic research seems to have been undertaken to find out the criteria used by commercial banks to select those to retrench. The proposed study is intended to fill this gap in knowledge.

\subsection{Research questions}

- What criteria do commercial banks in Kenya use to identify employees to be retrenched?

- What is the frequency of use of each criterion of retrenchment?

- Is there any association between the criterion used to determine those to be retrenched and size, age and ownership of the bank?

\subsection{Importance of the study}

The study will:

- Provide insight to organizations on the criteria used in identifying employees to retrench.

- Academicians wishing to enrich their knowledge in this concept of retrenchment.

- $\quad$ Researchers who may wish to develop the study further through subsequent researches.

\subsection{Scope of the study}

The study was carried out in the headquarters of all the commercial banks in Kenya, where the headquarters are all based in Nairobi. The target respondents were the Human Resource Managers of the banks.

\subsection{Theoretical framework}

This research is based on the contingency theory to the study of organizations and their management. The theory based upon the organismic analogy, views organizations as consisting of a series of interdependent subsystems, each of which has a function to perform within the context of the organization as a whole. The human subsystem embraces the people in the organization, their leadership, and their motivation. Contingency theory assumes that each of the subsystems is open to a range of variation. Each should be designed so that it is congruent with the others and corresponds to the environment with which it is faced. The size of the organization will also have an important effect upon the subsystems and the organizational structure. Contingency theory additionally rests upon the open systems view that regards the organization as dependent upon the wider environment. The organization and environment are seen as being in a state of mutual influence and interdependence. The economic performance of a firm decides whether it survives or not, and this is determined in turn by the way the organization manages its relationship with the environment.

Contingency theorists Kast and Rosenzweig (1985) suggest that a leaner organizational structure and reduced red tape increase flexibility and facilitate the fit between intra-organizational processes and the environment. Therefore, positive organizational results are ultimately expressed in the company's economic robustness. Economically, a key reason for downsizing is to reduce costs as organizations seek to maximize efficiency (Cascio et al., 1997) and business objectives can be best achieved with fewer employees. Several strategies seem pertinent, notably a cost leadership strategy which 
enables the organization to increase return on sales, or to increase market share through aggressive costing. Following staff downsizing the company can transmute the leaner cost structure into competitive advantage (Mentzer, 1996) by increasing profitability or lowering prices, which will be expressed in increased market share.

\section{Literature Review}

\subsection{The concept of downsizing and retrenchment}

Downsizing consist of an intentional set of activities undertaken by management of an organization in order to improve overall organizational efficiency, productivity and competitiveness which also results in the reduction of the number of employees required by an organization (Cameron et al, 1993). Downsizing therefore is expected to lead to lower overheads, less bureaucracy, faster and smoother decision making and overall increase in productivity levels of the firm (Sahdev et al., 1999).

Downsizing is the discharge of surplus employees due to down turn in business, the installation of labour saving machinery and standardization or improvement of plants and techniques. This will result in the reorganization of the employers undertaking; consequently some employees may be redundant and may have to be retrenched (Job-street journal). Retrenchment refers to the termination of employment of a permanent employee due to redundancy (www.google.com).

Retrenchment refers to the voluntary actions of an organization to reduce expenses (Bruce \& Green 2000). Many scholars have defined retrenchment as a purposeful reduction in the size of an organization's workforce (Cameron, Freeman and Mishra, 1991; Cascio, 1993).

\subsubsection{Reasons for retrenchment}

There are various strategic reasons for organizations to retrench. They include acquisitions and mergers, need to avoid bankruptcy, to prepare for privatization and to reduce costs to remain competitive in an increasingly global economy (Appelbaum, 1997). The expected outcomes of retrenchment include increased productivity, improved quality, enhanced competitive advantage, and potential regeneration of success (Hoskinsson and Hitt, 1994). In addition, organizations hope to achieve lower overheads, less bureaucracy, more effective decision making, improved communication and greater innovation (Burke and Greenglass, 2000) as a result of retrenchment. The retrenchment strategy may be seen as a method for increasing organizational change and regained effectiveness (Weitzel \& Jonsson, 1989).

Drew (1994) compartmentalized the factors that cause downsizing into three main categories; macroeconomic, industry specific, and company specific. Empirical evidence revealed that declines in sales (industry specific), declines in profits (industry specific), poor financial results (company specific), greater responsiveness to customer needs (industry specific), and increased international competition (macroeconomic) were the main downsizing driving forces for the surveyed firms. Mishra and Mishra (1994) assert that firms have downsized in order to cut costs, seeing few alternatives for coping with the increasingly competitive global market-place. They contend that the kind of downsizing that took place in the 1980s was mainly an effort to reduce the number of employees in order to remain competitive, a trend that continued well into the 1990s.

Ryan and Macky (1998) concluded that downsizing was employed not only to cut labor costs by shedding labor in the short run, but to apply downward pressure on wage demands from the remaining workforce in the longer term. Harrington (1998) attributes downsizing to surpluses of both employees and facilities. This in itself is seen as a direct result of increased competition, increased efficiency, reduced need for middle managers resulting from de-layering and employee empowerment, and improved quality and reliability of products which require fewer resources for maintenance. Luthans and Sommer (1999) concluded that global competition, technological innovation, increased customer influence, macroeconomic forces, and pressures from rival firms represented the main downsizing driving forces of the 1990s.

\subsubsection{Consequences of downsizing}

Gandolfi (2008) observed that downsizing activities produce profound consequences:

\section{Financial consequences}

The overall picture of the reported financial effects of downsizing is bleak (Gandolfi \& Neck, 2008). A multitude of studies, cross-sectional and longitudinal, have shown that while some firms have reported financial improvements (Sahdev, 2003), the majority of downsized firms have not been able to reap improved levels of efficiency, effectiveness, productivity, and profitability (Gandolfi, 2009). The downsizing literature portrays an overwhelmingly negative picture of the financial benefits of downsizing. There is strong evidence suggesting that a pure downsizing strategy is unlikely to be effective (Macky, 2004). Many downsizing efforts have shown to produce financial results that are dismal and economic consequences that are devastating (Burke \& Greenglass, 2000). 


\section{Organizational consequences}

Downsizing is expected to generate financial and organizational benefits (Palmer, Kabanoff, \& Dunford, 1997). The major economic benefit that is expected is a direct increase in shareholder value. The rationale is that future costs are more predictable than future revenues and cutting costs should translate into higher profits. Since people represent a considerable component of operating costs, the cutting of employees seems a rational, natural response. Anticipated organizational benefits include lower overheads, less bureaucracy, faster decision making, smoother communications, greater entrepreneurship, and increased productivity(Burke \& Cooper, 2000).

\section{Human consequences}

Downsizing-related human costs are extensive (Gandolfi, 2009) and far-reaching (Burke \& Greenglass, 2000).

Downsizing scholars have identified and empirically studied the symptoms associated with the emotions behaviors, and attitudes of survivors. These symptoms have come to be known as 'sicknesses'. The most prominent sickness, the survivor syndrome, is a set of emotions, behaviors, and attitudes exhibited by surviving employees (Littler, 1998). Downsizing engenders a variety of psychological states in survivors, namely, guilt, positive inequity, anger, relief, and job insecurity. These mental states have the potential to influence the survivors' work behaviors and attitudes, such as motivation, commitment, satisfaction, and job performance. The survivor syndrome is characterized by decreased levels of morale, employee involvement, work productivity, and trust towards management (Cascio, 1993).

\subsubsection{Effect of poor retrenchment decisions on survivors}

When poor decisions are made regarding employees to let go such that the wrong employees are released of their duties, this may affect the survivors in many ways.

The victims of retrenchment have been shown to suffer from shock, grief, disbelief, anger and feeling of betrayal, fear, shame, embarrassment, fantasy and despair. The survivors are also affected by the dismissal or exit of their colleagues. They suffer from fear, insecurity and uncertainty, frustration, resentment and anger, sadness, depression and guilt, injustice, betrayal and mistrust (Tylezak, 1991).

These negative effects lead to the "survivor syndrome" (Noer, 1993), which is manifested in a variety of ways through a spectrum of attitudes and perceptions. It has been noted that if these problems are neglected or mishandled or worse still if their existence is denied, the consequences for the organization can be severe if not devastating. The response of employees to retrenchment is influenced by their cognitive appraisal of the problem.

The surviving workers experience difficulty in coping with bigger workloads because they take over the duties of their former colleagues who become victims of retrenchment. One negative response among surviving employees is increased absenteeism and sick-offs with obvious costs to the organization and the society. Retrenchment may exacerbate the "classic" equation for stressful working conditions (Cox, 1993; Karasek and Theorell, 1990), increased job demands, decreased job control and decreased social support - and it is entirely possible that such an effect may partly mediate its other effects on absence and health.

Survivors of retrenchment report work-related stress dissatisfaction and intent to leave the organization, increased guilt and decreased morale and productivity (Brockner, 1998).

The survivors' attitudes and behaviours are consistently negative, where perceived justice was low, organizational trust and support were highly related to perceived outcome negativity (Brocker et al., 1993). These negative reactions combined with the fact that survivors must do more, with few resources makes the aftermath of layoffs difficult to deal with.

\subsubsection{Effect of poor retrenchment decisions on leavers}

Poor decisions in identifying employees to retrench affect the victims of a layoff such that they exhibit various reactions. Research indicates that the reactions of leavers include anger, shock, disbelief, denial etc as depicted in table 1. These may later translate to feelings of betrayal, resentment, insecurity, powerlessness, and deeper-seated feelings (Richard, Bransted \&Milan, 1996; Hall and Goodale, 1986).

Charles (1974) has suggested ways of making retrenchment less painful to the leavers. He has recommended a set of objectives such as relocation of separated employees, alleviation of psychological and economic strains, and exercising good community citizenship.

These objectives are elaborated below: 


\section{Relocation of separated employees}

When a cutback in staff occurs, many people will become confused. Unaccustomed to job hunting, they often will not know what to do with the result that they do nothing to find new work. Their attitudes towards the future become sour. The best thing the personnel department can do to prevent this is to assist these people to find new jobs so their income stream will not be interrupted. This is largely a matching process. It involves identifying employment opportunities, introducing prospective employees to employers, and assisting the prospective employees to make their capabilities known to employers by well-prepared resumes and personal interviews.

\section{Psychological and economic strains}

These can be alleviated by dealing honestly and directly, but understandingly and supportively with employees. Be direct and helpful with your people and be available for them; Clearly and early announce the retrenchment, the date when the exercise will be done and the reasons for the decision. Communicate the retrenchment far enough in advance so that people have adequate time to find new work. Start your assistance program to help people find new jobs some time well before their projected separation date, so that they know the retrenchment is really coming and do not cling to false hopes which are sure to be shattered; Advise personnel on their rights to company benefits, the amount of their severance pay, time of payment etc. Make available information on social security, unemployment compensation, and other assistance available to unemployed people; Provide counseling and advice on where to obtain direct help on career plans and financial problems caused by the loss of a job.

\section{Good community citizenship}

This can be enhanced by becoming a responsible organization, and not taking the "I don't care "attitude towards the community; Arrange for company officials, company staff in charge of the relocation assistance program, community leaders, and members of the local chamber of commerce to meet, with the purpose of working together constructively to anticipate, avoid, or at least alleviate possible economic strains on the community; Make these joint efforts known to the local news media and your employees; Make known the company's relocation assistance program to the local news media; Publish periodic reports in local newspapers regarding the progress of relocation efforts. For example, the company could publish the percentage of people who have found new jobs.

\subsubsection{Role of management in retrenchment}

Concerning displaced workers, management should make the transition as easy as possible. Employees should have ample notice of the lay-off so that they can begin to look for new work. Many companies also offer programmes, that train people in skills so that they have a broad range of knowledge and can be better qualified to go back into the workforce. Another popular trend of companies is to offer classes to train people in a different field. In the workplace today, many programmes are available to help displaced workers with resumes and recommendations for new jobs. Mainly, employers should be compassionate and empathetic towards their employee's struggle. Since managerial behaviour can dictate the attitude of remaining employees, management should give support to displaced workers. If the victims received unfair treatment or compensation, survivors are more apt to exhibit negative attitudes, reduced work performance, and lowered commitment. However, if survivors believe the company displayed some responsibility to displaced workers, production will increase (Makawatsakul and Kleiner, 2003).

Burke and Nelson (1998) reported that employees were more negative and even hostile when they believed that procedures leading to the lay-offs were unfair, when they were not given sufficient advance notice, and when they perceived unfair treatment during the downsizing efforts. Managers can take several steps to ensure that employees remain loyal, productive, and happy. The most important step is to communicate all information (good and bad) to employees clearly and in a timely fashion. Communication should be open and honest. In response to rumours that circulate, employees spend significant amounts of time agonising and speculating about the future instead of working. Information should be communicated several times and in different ways. The downsizing should also be personal, with physical contact instead of e-mails or memos. Employees are not simply grateful to have a job; they need to feel valued and needed.

Managers must have faith in the company to strengthen and encourage survivors after downsizing.

\subsubsection{Characteristics of effective retrenchment}

According to Burke and Nelson (1998) effective retrenchment should have the following characteristics:

- $\quad$ Retrenchment should be implemented by command from the top, with recommendations from lower level employees, based on job and task analyses of how work is organised. 
- The management develops a change-management plan with a clear vision especially of the ideal future organisational identity and specific steps to conduct and oversee the transition.

- Management should pay special attention in the form of outplacement, generous severance pay, retraining, and family counselling to those employees who lost their jobs. In addition, the management should create placement opportunities and allow reasonable time for employees to find jobs elsewhere. Those employees who did not lose their jobs received special attention through increased information exchange among top managers and employees.

- Through internal data gathering and data monitoring, firms identified precisely where redundancy, excess cost, and inefficiency existed. They then attacked these areas specifically.

- $\quad$ Organisational leaders should facilitate downsizing by preparing for a high level of activity, rallying people with a vision of a better organisation, offering transition management training, acknowledging uncertainty and concerns, communicating plans and actions, telling the truth, involving people in managing the transition, and establishing a safety net for transition victims.

\subsubsection{Retrenchment process}

Burke and Nelson (1998) further contend that a successful retrenchment process requires planning that begins long before the formal announcement, which can be divided into four steps:

\section{Making the Decision to Retrench}

The decision to retrench must be made with care. Employees often see retrenchment as a failure by top management to control costs and hiring in the first place. It also represents a failure to count employees as valued assets but to see them simply as costs. Managers can show their concern by exhausting all possible alternatives before deciding to retrench. For shortterm declines, some companies have successfully implemented hiring freezes, salary freezes, overtime restrictions, pay cuts, elimination of bonuses, shortened work weeks, or unpaid vacations. Companies can offer voluntary separation with severance benefits or early retirement. The real danger in offering voluntary separation is that the best performers may be the first to leave because they have the most attractive employment alternatives. Thus, companies must manage such separations carefully to avoid losing people with key skills or competencies. Only after the company offers other alternatives and voluntary separations should it consider forced lay-offs. This approach shows employees that management is concerned about their interests and needs rather than just its own short-term needs to reduce costs. While this approach may take longer and incur upfront costs, it will pay for itself in the long term through survivors' increased trust.

\section{Planning the Retrenchment}

The implementation plan must consider all stakeholders' needs. Laid-off employees and survivors must trust that management is concerned with their needs, not just those of shareholders, so they feel in control of their destiny, even if it involves lay-offs.

- Form a cross-functional team. The team to plan and implement the retrenchment should represent all members' interests so employees see that management is looking carefully at everyone's needs and concerns.

- $\quad$ Provide training to managers. Training should explain how to communicate the retrenchment announcement empathetically and convincingly. It should give the managers who execute the lay-offs skills and practice in telling employees that they will lose their jobs. Some laid-off workers will be unable to comprehend what is happening and will lash out at the messenger or become violent. However, managers prepared to deal with their emotions and those of employees in advance can feel competent in executing this difficult task. Often these managers need counselling and support after they share the news with employees to deal with their own guilt and stress.

\section{Making the Announcement}

At this stage, the company must not only show concern for employees' needs (whether survivors or laid-off workers) but must also be open and honest about the reasons for the retrenchment and the implementation process, thus helping to mitigate distrust. The company must communicate its vision so that survivors can have a sense of hope and personal control about the future and feel empowered. Severance packages and other benefits for retrenched employees are critical so that they feel in control and can find other employment.

- $\quad$ Explain business rationale. Managers should explain to employees where the company is headed. Employees should know why retrenchment would help rejuvenate the organisation. Communicating a clear vision helps them trust management's competence in turning the company around. If they see the larger vision, they will also feel more in control. 
- $\quad$ Notify in advance. Advance notice helps employees feel in control so that they can better plan their futures. It also enhances their trust in management's openness and willingness to share sensitive information.

- Be specific and time the announcement appropriately. Employees want to hear about their company's retrenchment from the organisation itself, not from the newspaper or television. Thus, it is critical to communicate the retrenchment announcement simultaneously to all affected constituencies.

Implementing the Retrenchment

- $\quad$ Tell the truth and communicate. A company should anticipate employees' questions and answer them throughout the implementation phase. It should ensure time to listen and understand employees' concerns and needs.

- Help departing employees find other jobs. The crisis is not over until departing employees are gainfully re-employed. Sometimes employees can be absorbed into other parts of the business. Outplacement agencies can facilitate employment in new firms.

- Be fair in implementing separations and be generous to laid-off workers. Survivors will judge a company's future interactions with them on how fairly it treats those laid off. The selection process should focus on past performance or some other objective criteria, and the criteria should fit with the vision of the future.

- A company should also provide generous benefits so workers feel treated. Outplacement services can include career counselling, stress management, skills assessment, retraining reimbursement, and job placement assistance such as secretarial support, job fairs, resume preparation, and interview training. Generous benefits repay themselves by making survivors more positive about the retrenchment.

- Involve employees in retrenchment implementation. A well-implemented downsizing focuses not only on removing employees but also on changes in work design. Remaining employees often have ideas about restructuring their jobs and improving internal processes, so companies should involve them.

- $\quad$ Train survivors. It is easy to assume that the survivors will know how to carry out their responsibilities after the workforce is downsized. Nevertheless, they may feel overburdened in taking on the jobs of former co-workers that require different skills. Training should give them confidence to work in a new environment.

\subsection{Criteria for retrenchment}

Criteria a firm can use to select employees to retrench include seniority systems, unsatisfactory performance, incapability, ill-health, misconduct and early retirement programs. These criteria are discussed in greater details below.

\subsubsection{Seniority systems}

Flippo (1984) observed that seniority is a stronger factor in layoff than it is in promotion decisions. In one survey of union-management contracts, seniority was the sole factor controlling layoff decisions in $25 \%$ of the contracts, a primary factor in one-half (seniority controlled if the more senior employee could meet minimum performance requirements), and a secondary factor in the remainder (seniority controlled only if the more senior employee was relatively equal in ability to the person to be replaced).

This system involves laying the least senior people in each job class. Cutting the same percentage of employees from each job class would make retrenchment process completely objective and automatic. The system has several advantages. The system ends reliance on subjective employee evaluations, and would generate few legal challenges. It reduces morale effects and pressure to search for other jobs if one is "safe" and finally, it removes some of the stigma that unjustifiably attaches to retrenchment. Seniority based system has disadvantages, however. Low morale and pressure to search for other jobs are still felt by all employees, even if the pressure is eased for some people. There is no incentive to improve productivity. Positions are cut regardless of need (Harry, 1983).

\subsubsection{Unsatisfactory performance}

This may be defined as a persistent failure to perform assigned duties or to meet prescribed standards on the job. Specific reasons here include excess absenteeism, tardiness, a persistent failure to meet normal job requirements, or an adverse attitude towards the company, supervisor or fellow employees (Flippo, 1984).

Employers may find that performance appraisal schemes provide a useful structure for establishing fair and objective selection criteria and that the use of appraisal data can help to ensure that the act of selection is not itself unfair (Lewis, 1992).

\subsubsection{Incapability}

It is fair to dismiss an employee on the grounds of capability or qualifications, but subject to the test of reasonableness. 
Capability refers to skill, aptitude, or any other physical or mental quality. Qualifications mean any 'degree, diploma or other academic, technical or professional qualification'. In practice, dismissals on the grounds of capability are those involving incompetence. where incompetence reflects the fact that the employee is working below capacity rather than a lack of ability, the issue is to be treated as one of misconduct rather than one of capability. Loss of confidence in an employee, more likely in a management position, can amount to incompetence (Lewis, 1992).

\subsubsection{Ill-health}

In ill-heath dismissals much depends on the context. A dismissal in a small firm will often be fair, while in a larger firm, where the work can be 'covered', it may well be unfair. The nature of the job will be a consideration too. At some stage, provided a proper procedure has been followed, an ill-health dismissal is likely to be fair. The procedural necessities include ascertaining the medical position and consulting with the employee (Lewis, 1992).

\subsubsection{Misconduct}

Misconduct may be defined as deliberate and willful violation of the employer's rules and may include stealing, rowdyism, and insubordination (Flippo, 1984). Certain offences normally attract the label 'gross misconduct'. These include theft, physical violence, drunkenness, breach of confidence and refusal to carry out a legitimate order. Gross negligence in the absence of any element of intention, does not amount to gross misconduct. The employer may consider the level of misconduct of various employees in the past (Lewis, 1992).

\subsubsection{Early retirement programs}

Many organizations have resorted to early retirement programs as a criterion for reducing the size of the workforce. Research indicates that prospective retirees predict far more dissatisfaction with the retirement role than they actually experience after leaving the organization. Properly designed programs can do much to lessen these anxieties.

Flippo (1984) noted that whether cause or effect, it is evident that retirement is a major event in one's lifecycle, and the organization has a major responsibility in facilitating the transition from one stage to the other. People must become able to accept the idea that one can successfully live in dignity as an adult without having a job.

He further noted that retirement programs can also provide considerable values for the organization and society at large. Successful retirees are walking ambassadors of good will for the organization. They reduce the burden on the firm's personnel department after retirement in as much as most of their questions have been answered. It is also possible that their productivity in the few years prior to retirement has been enhanced because of the lessening of anxiety about the future. Society in general also profits from successful programs. Retirees possess a valuable societal resource-a daily supply of free time. Programs that inform prospective retirees of places where they can continue to serve in voluntary organizations enhance society's wealth. Programs that enhance greater self-sufficiency in financial planning can do much in enhancing retirees' lives thereafter (Flippo, 1984; Hall and Goodale, 1986).

Armstrong (2001) suggested other criteria which included: changed requirements of the job which is an employee's incapability of doing the work assigned after the nature of the job has been changed; a legal factor that prevents the employee from continuing work; the employee broke or repudiated his or her contract by going on strike-as long as he or she was not singled out for this treatment, that is, all striking employees were treated alike and no selective re-arrangement took place; the employee was taking part in an official strike or some other form of industrial action.

There is an overlap of criteria of retrenchment, where unsatisfactory performance having been defined as persistent failure to perform assigned duties or to meet prescribed standards on the job, may also be as a result of incapability, which is lack of required skills to do a job.

\subsection{Steps in the selection process of a criterion}

Enterprise Business Centre's Information Resource Centre (2001) pointed to the following steps in the selection process as good human resources management practice:

- Follow any award or agreement provisions on selection.

- Decide on a method for selection if no guidelines exist (refer to the table below for options on selection methods).

- If there is no agreement with a union, consult with the union to establish selection methods (otherwise, it is good practice to inform the union of what the selection methods were/will be).

- When deciding on selection methods, consider matters such as length of service, job performance, experience, attendance and work records, the availability of alternative employment and how to best serve the commercial needs of the enterprise. 
- $\quad$ Take into account more criteria than length of service alone.

- $\quad$ Consider the organization's future staffing needs, not only the current effect staffing has on profitability.

- $\quad$ Review all possibilities of internal transfer, especially for senior or long serving staff.

- $\quad$ Provide procedural fairness in the retrenchment. Use fair and objective selection criteria, apply the criteria in a fair way without preconceived notions of the best outcome, consider the alternatives to minimize terminations, consult with the union, if applicable as a matter of good practice, and to minimize the risk of actions for unfair dismissal, consult with employees and provide procedural fairness in all redundancies.

- $\quad$ Ensure selection meets equal opportunity and anti-discrimination laws, and any organization policies.

- $\quad$ Ensure that the reason for termination is not prohibited under the relevant legislation.

Employers can use this selection assessment as a guide to help clarify the selection process and to ensure the process is more carefully thought out and objective. Employers do not need to adopt all the criteria listed. However, an assessment based on a wide range of criteria is more likely to be seen to be fair (Enterprise Business Centre's Information Resource Centre, 2001). Methods used in selecting potential retrenchees are presented in table 2.

\section{Research Methodology}

\subsection{Research design and population}

This was a descriptive study. It was a census survey and the population consisted of the Human Resource Managers of the 43 banking institutions in Kenya which had retrenched in the past three years (See Appendix 3). These banks have their head offices situated in Nairobi though they have branch networks in other towns. The list of these banking institutions was adapted from a study by Mwangi Elizabeth Nyaikamba (2002), which was obtained from the Federation of Kenyan Employers, and is attached as appendix 3.

\subsection{Data collection}

The study largely utilized primary data. The data was collected using a questionnaire. The questionnaire consisted of both closed and open-ended questions. The questionnaire was divided into two sections. Section A sought bio-data of the respondents and organizations while Section B addressed aspects of retrenchment, mainly the criteria used in identifying employees to retrench. The questionnaire was administered on a 'drop and pick up later' basis.

\subsection{Data analysis}

Descriptive statistics were used to summarize the data. These included frequencies, percentages and mean scores, which were used to determine the criteria used in identifying employees to retrench. For example, the criteria with the highest frequency as well as percentage were deemed as the most popularly used. Open-ended questions were content analyzed, and used to explain responses to closed-ended questions to which they applied.

Cross tabulations were used to check for any association between the techniques used to select the employees to retrench and organizational factors such as age, ownership and size. Analyzed data was presented in form of tables.

\section{Data Analysis and Findings}

\subsection{Introduction}

The data from the study was summarized and presented in percentages, frequencies and tables. Out of the 43 Human Resource Managers who comprised the population of the study, 20 completed the questionnaires. This was approximately $47 \%$ of the target. Some of the banks had not carried out any retrenchment, and were therefore not in a position to respond to questions that addressed the criteria used by commercial banks in Kenya to identify employees to retrench.

The analysis was presented as follows:

- $\quad$ Data on the respondents profile and the organization.

- $\quad$ Data on the criteria used to identify employees to retrench.

- Data on the association between the criteria used to identify employees to retrench and age, ownership and size of the organization.

\subsection{Type of respondents}

From Table 3, it can be observed that the respondents were $75 \%$ male and $25 \%$ female. This is indicative of the male domination of the human resources function in the banking industry. Majority of the respondents were Human Resource 
Managers (60\%), followed by Assistant HR Manager (20\%), HR Dev. Manager (15\%) and Human Resources Advisor (5\%). These results are presented in Table 4.

The findings presented in Table 5 indicate that majority of the heads of Human Resources department in the banking industry have the title of Human Resource Manager (55\%), while other titles are Group HR Director (20\%), Chief HR Manager (20\%), and General Manager (5\%). As shown in Table 6, the experience of the HR experts within the various commercial banks in Kenya had a range of between 0 and over 24 years, with $50 \%$ having experience of 0-8 years, $35 \%(9-16$ years), $10 \%(17-24$ years) and $5 \%$ over 24 years.

Table 7 depicts that majority of the banks studied have been in existence in Kenya for a period between 11-20 years $(35 \%)$ and over 30 years $(50 \%)$. The period of existence is rather long indicating that the Kenyan market must be fairly favourable and making some good returns to the shareholders. Those that existed for less than 10 years constituted $10 \%$ and those between 21 and 30 years were $5 \%$.

From Table 8, it can be observed that majority of the commercial banks (75\%) have less than 500 employees, while $15 \%$ of the banks have over 1500 employees and 5\% have between 500 and 1500 employees.

The analysis indicates that $60 \%$ of commercial banks in Kenya are locally owned; while $20 \%$ are foreign owned and $20 \%$ are a combination of local and foreign owned. These results are presented in Table 9. From Table 10, it is clear that only $20 \%$ of the banks are joint venture while $80 \%$ of the banks are either locally or foreign owned. From the banks that are a joint venture, $75 \%$ are largely foreign owned, while $25 \%$ are largely locally owned.

The size was determined by the value of assets owned by the banks. Banks with assets over Ksh $5000 \mathrm{M}$ were classified as large, assets between Ksh 3000M and Ksh 4999.9M as medium, and assets between Ksh 0 and Ksh2999.9M as small. As shown in Table 11, 55\% of the respondents were from large banks, $25 \%$ were from medium banks and $20 \%$ were from small banks. From Table 12, it is evident that out of the total respondents, $65 \%$ of the banks had a retrenchment policy in place, while $35 \%$ of the respondents did not have a retrenchment policy.

The findings of the study presented in table 13 , show that $60 \%$ had retrenched once, $25 \%$ had retrenched twice and $15 \%$ had done it more than 3 times within the last 5 years.

From Table 14, 45\% of the banks that had retrenched provide outplacement services to the employees leaving. These services include counseling on managing post-retrenchment effects. This is healthy for the organization and employees because if this is not done, it has got far-reaching implications on the survivors. Other outplacement services include financial management and opening up of new businesses, recommendation letters/ contacts of prospective employers and career workshops. However, $55 \%$ of the banks that had retrenched did not provide any outplacement services to the leavers.

$100 \%$ of the respondents said that they had a performance appraisal system in place. This shows that the daily progress/ performance of the employees is measured. Those banks that use employees' individual productivity in making retrenchment decisions solely rely on this assessment. These results are presented in Table 15.

\subsection{Criteria used in determining employees to retrench}

Table 16 shows that $5 \%$ of the respondents used the last-in first-out method as a criterion for retrenchment to a very great extent, $10 \%$ to a great extent, $35 \%$ to a moderate extent, $25 \%$ to a less extent, and $525 \%$ did not use the method at all. As shown in Table 17, 60\% of the respondents considered employees' individual productivity in the retrenchment decision to a very great extent, $35 \%$ to a great extent, and $5 \%$ to a moderate extent.

From Table 18 above, it can be observed that $40 \%$ of the respondents considered misconduct as a criterion for retrenchment to a very great extent, $20 \%$ to a great extent, $20 \%$ to a moderate extent, $5 \%$ to a less extent, and $15 \%$ did not consider it at all. $25 \%$ of the respondents considered incapability as a criterion for retrenchment to a very great extent, $15 \%$ to a great extent, $15 \%$ to a moderate extent, $20 \%$ to a less extent, and $25 \%$ did not consider it all. These results are presented in Table 19. From Table 20, it shows that $15 \%$ of the respondents used early retirement programs as a criterion for retrenchment to a very great extent, $20 \%$ to a great extent, $25 \%$ to a moderate extent, $25 \%$ to a less extent, and $15 \%$ did not use it at all.

\subsection{Association between criteria used and age of a bank}

Cross tabulations were used to establish whether there was any association between the criteria used and age of a bank.

From Table 21, it shows that most of the banks that used LIFO method but to a moderate extent were those that have existed for a period between $11-20$ years $(15 \%)$ and over 30 years $(20 \%)$. Table 22 shows that majority of the banks $(60 \%)$ that used employees individual productivity to a very great extent had been in existence for over 11 years, while 
those that used it to a great extent, (5\%) had existed for less than 10 years, (15\%) between 11-20 years, and (15\%) over 30 years. Only $5 \%$ used the method to a moderate extent and these are the banks that had existed for less than 10 years.

Table 23 shows that the banks that used misconduct as a criterion to a very great extent, (5\%) had existed for less than 10 years, $(10 \%)$ between $11-20$ years, $(5 \%)$ between $21-30$ years, and $(20 \%)$ over 30 years. Incapability as a criterion was used to a very great extent $((25 \%)$ by banks that had existed for over 30 years, the banks that used it to a less extent, (10\%) had existed between 11-20 years, and (5\%) between 21-30 years and over 30 years respectively. Those that did not use the method at all (5\%) had existed between $0-20$ years and $(15 \%)$ over 30 . These results are presented in Table 24.

From Table 25, it is evident that the banks that used early retirement programs to a moderate extent, (10\%) had existed for a period between 11-20 years, (5\%) 21-30 years and (10\%) for over 30 years. Those that used it to a less extent, (15\%) had existed between 11-20 years and (10\%) for over 30 years. The banks that used LIFO method but to a moderate extent, had existed for a period between 11-20 years and over 30 years. Those that used employees' individual productivity to a very great extent had existed for over 11 years. Misconduct as a criterion has been used to a very great extent by banks that had existed for over 11 years. Incapability had been used to a very great extent by banks that had existed for over 30 years. Early retirement programs had been used to a moderate extent by banks that had existed for over 11 years and to a less extent by banks between 11-20 years and over 30 years.

\subsection{Association between criteria used and size of a bank}

Table 26 shows that most of the banks that used LIFO method but to a moderate extent (20\%) were large, (5\%) medium and $(10 \%)$ were small. Those that used the method to a less extent, $(10 \%)$ were large and small respectively while $(5 \%)$ were medium. However, $(20 \%)$ of the large banks and $(5 \%)$ of the small banks did not use the method at all. From Table 27 , it is observed that majority of the banks $(60 \%)$ that used employees individual productivity to a very great extent, $(35 \%)$ were large, $(15 \%)$ medium, and $(10 \%)$ were small, while those that used it to a great extent, $(15 \%)$ were large, $(5 \%)$ medium, and (15\%) were small. Only small banks (5\%) used the method to a moderate extent.

As shown in Table 28, most of the banks that used misconduct to a very great extent (40\%), (15\%) were large and small respectively, and (10\%) were medium. (5\%) of large and small banks respectively, and (10\%) of the medium banks used it to a great extent whereas $(10 \%)$ of large and small banks respectively used the method to a moderate extent.

$(20 \%)$ of large banks and $(5 \%)$ of medium ones used incapability as a criterion to a very great extent, while $5 \%$ of all bank sizes used it to a great extent. (15\%) of large banks and (10\%) of small ones did not use the method at all. These results are presented in Table 29. From Table 30, it can be observed that (15\%) of large banks and (5\%) of medium and small banks respectively used early retirement programs to a moderate extent, while (10\%) of medium and small banks respectively, and $5 \%$ of large ones used the method to a less extent. However, (15\%) of large banks and 5\% of small ones used it to a great extent.

LIFO method was used to a moderate extent by banks that were large, medium and small. These banks had used employee's individual productivity to a very great extent. They also used misconduct as a criterion to a very great extent. Incapability was used to a very great extent by large and medium banks, while early retirement programs had been used to a moderate and less extent by all sizes of banks.

\subsection{Association between criteria used and ownership of a bank}

LIFO method was used to a moderate extent by $(20 \%)$ of locally owned banks, $(10 \%)$ of foreign owned and $5 \%$ of joint ventures. The banks that used the method to a less extent, $(15 \%)$ were locally owned, and $5 \%$ were foreign owned and joint ventures respectively. $10 \%$ of locally owned banks and $15 \%$ of joint ventures did not use the method at all. The results are presented in Table 31. As shown in Table 32, employees individual productivity was used to a very great extent by $30 \%$ of locally owned banks, $20 \%$ of foreign owned, and $10 \%$ of joint ventures. The method was used to a great extent by $20 \%$ of locally owned banks, $5 \%$ of foreign owned and $10 \%$ of joint ventures.

As shown in Table 33, misconduct was used as a criterion to a very great extent by $20 \%$ of locally owned banks, $15 \%$ of foreign owned, and $5 \%$ of joint ventures. $15 \%$ of locally owned banks and $5 \%$ of joint ventures used it to a great extent, and $15 \%$ of locally owned banks and $5 \%$ of foreign owned banks used the method to a moderate extent. From Table 34, incapability as a criterion was used to a very great extent by $10 \%$ of locally owned banks and joint ventures respectively, and $5 \%$ of foreign owned banks. $15 \%$ of locally owned banks and $5 \%$ of joint ventures used it to a less extent, and the banks that did not use the method at all, 10\% were locally owned and joint ventures respectively, and 5\% were foreign owned. 
As shown in Table 35, early retirement programs were used to a moderate extent by $15 \%$ of locally owned banks, and to a less extent by $15 \%$ of locally owned banks and $5 \%$ of foreign owned banks and joint ventures respectively. LIFO method was used to a moderate extent by banks that were locally owned, foreign owned and joint ventures. Employees' individual productivity had been used to a great extent by banks that were locally owned, foreign owned and joint ventures. Misconduct as a criterion had also been used by these banks to a very great extent. Incapability had been used to a very great extent by all these banks, while early retirement programs had been used to a moderate extent by locally owned banks, and to a less extent by all these banks.

\section{Summary and Conclusions}

This chapter summarizes the findings of the study. It also includes conclusions, limitations of the study and suggestions for future research.

\subsection{Summary of the findings}

The first objective of the study was to establish the criteria used by commercial banks in Kenya to determine employees to retrench. The second objective was to establish the frequency of use of each criterion, and thirdly, the study was to determine if there was any association between the criteria used to determine those to be retrenched and age, ownership and size of the organization.

From the study it is noted that the commercial banks used seniority (Last-in first-out), employees' individual productivity, misconduct, incapability, early retirement programs, first-in first-out (FIFO) and employee obsolescence as criteria for determining employees to retrench.

The criterion that was most popularly used was assessment of employees' individual productivity. All the respondents had a performance appraisal system in place where the daily progress of employees was measured. These records played a very big role in making retrenchment decisions. Misconduct as a criterion for retrenchment was also popular and some of the behaviors that banks considered as misconduct include fraud, insubordination, regular unauthorized absenteeism, financial mismanagement, leaking out confidential information, alcoholism, and negligence among others. Early retirement programs were also used to a moderate extent. Incapability as a criterion was used to a less extent.

As shown on the cross tabulation of various criteria and age, ownership and size of the organization, it is evident that there is no association between the criteria used and age, ownership and size of the organization. All banks used the same criteria despite their age, ownership and size.

\subsection{Conclusions}

The findings of the study point to the fact that commercial banks in Kenya use various criteria for determining employees to retrench, which include seniority (First-in first-out), employee individual productivity, misconduct, incapability, early retirement programs, First-in first-out (FIFO), and employee obsolescence.

The criterion that is most popularly used is assessment of employees' individual productivity through performance appraisal systems. Misconduct is also popularly used as a criterion, and for those banks that have early retirement programs, this is a very popular approach. It is advisable for commercial banks to use a combination of two or more criteria so that objectivity is observed. The findings of the study also point to the fact that similar criteria are used by banks irrespective of their age, ownership and size.

\subsection{Limitations of the study}

The researcher faced the following limitations:

The response rate was not as high as expected because some would-be respondents failed to return their questionnaires, while others declined to be involved in the study claiming that in so-doing, they would be going against the organizational policy. Out of the forty-three questionnaires that were distributed, only twenty were collected. The contents of the study would have been richer if a larger number of respondents were involved. The response rate was too low to allow for the use of statistical tests.

\subsection{Suggestions for further research}

A similar study can be conducted in another industry to check whether there is similarity in the criteria used in determining employees to retrench across the board.

A study can also be done to establish the fairness involved in applying the various criteria for retrenchment. 


\section{References}

Appelbaum S. H. (1997). Literature Review on Corporate Retrenchment, University of Manchester.

Armstong. M. (1999). Human Resource Management Practice, London, UK, Kogan Page Ltd, $7^{\text {th }}$ edition.

Armstrong. M. (2001). Human Resource Management Practice, London, UK, Kogan Page Ltd, $8^{\text {th }}$ edition.

Brockner J. (1993), Threat of future layoffs, self-esteem and survivors' reaction. Evidence from the laboratory and field, Strategic Management Journal 14: 153-166. doi: 10.1002/smj.4250140912, http://dx.doi.org/10.1002/smj.4250140912

Brockner J. (1998). The effects of work layoffs on survivors: Research theory and practice in Staw B. M. and Cummings L. L. (Eds), Research in organizational behavior Vol 10, pp 213-255, Greenwich, C.T:JAI Press. ISBN 13: 978-0-7623-1054-8

Burke R.J and Cooper C.L (2000a). The organization in crisis: Retrenchment, Restructuring and Privatization; Blackwell Publishers.

Burke R.J and Greenglass, E. R. (2000). Constraining organizational restructuring: Identifying effective hospital retrenchment process. In Burke, R. J. and Cooper, C.L, The organization in crisis Retrenchment, Restructuring, and Privatization, pg284-303.

Burke, R.J. \& Nelson, D. (1998). Merger and acquisitions, downsizing, and privatization: A North American perspective". In M.K. Gowing, J.D. Kraft, \& J.C. Quick (Eds.), The new organizational reality: Downsizing, restructuring, and revitalization: pp.21-54. Washington, DC: American Psychological Association. doi:10.1037/10252-001, http://dx.doi.org/10.1037/10252-001

Burke, R.J., Cooper, C.L., (2000b). The new organizational reality: transition and renewal, In R.J. Burke and C.L. Cooper (eds), The Organization in Crisis (pp. 3-19), Blackwell Publishers, Malden, MA

Cameron K. S., Freeman S.J and Mishra A.K (1993). Organizational Retrenchment in organizational change and redesign: Ideas and insights for improving performance, New York, pg 19-25.

Cameron K., Freeman S.J and Mishra A.K (1991). Best practices in white- collar retrenchment: Managing contradictions. Academy of Management Executive, 5, 57-73.

Cascio, W.F., Young, C.E., Morris, J.R. (1997). "Financial consequences of employment-change decisions in major US corporations", Academy of Management Review, Vol. 40 pp.1175-89. doi:10.2307/256931, http://dx.doi.org/10.2307/256931

Cascio,W. F. (1993). Retrenchment: What do we know? What have we learned? Academy of Management Executive 7(1):95-104.

Central Bank of Kenya, Supervision Annual Report ( 2001).

Charles E. W. (1974). A sensible approach to mass layoffs, Journal of the international personnel management association, May-June, pg 233-237.

Cox, T. (1993). Stress research and stress management: Theory to work Health and safety Executive; London.

Decenzo, D. R. (1998). Personnel/Human Resource Management, Prentice Hall Publishers.

Drew, S.A.W., (1994). “Downsizing to improve strategic position”, MCB Management Decision, 32, 1

Enterprise Business Centre's Information Resource Centre (2001). www.ebc.com.au.

Flippo E.B (1984). Personnel Management, McGraw- Hill, Inc, $6^{\text {th }}$ edition.

Gandolfi, F., (2008). "Reflecting on downsizing - what have managers learned?" SAM Advanced Management Journal, $73(2), 46-56$

Gandolfi, F., (2009a). "Where did downsizing go? A review of 30 years of a strategic business phenomenon", The Australasian Journal of Business and Social Inquiry, 7 (1), 40-65

Gandolfi, F., (2009b). "Unravelling downsizing - what do we know about the phenomenon?", The Review of International Comparative Managementy, Volume 10, Issue 3414.

Gandolfi, F., Neck, P., (2008). "Consequences, payoffs, and fallout of downsizing (A literature review of corporate downsizing: Part 3)", Review of International Comparative Management, 9 (1), 55-78 
Guyo, C. H (2003). A survey of the practices of staff downsizing among the major oil firms in Kenya, MBA Project, University of Nairobi.

Halcrow A. (1997). "HR Practices at ACC Communications". http://www.google.com.

Hall D.T. and Goodale J. G (1986). Human Resource Management Strategy, design and implementation, London, England, Scott Foreman and company.

Harrington, H.J. (1998). "Performance improvement: the downside to quality improvement (the surplus people problem)”, The TQM Magazine, 10 (3) pp 154-160. doi:10.1108/09544789810219391, http://dx.doi.org/10.1108/09544789810219391

Harry C. D. Jr (1983). “Reduction in Force', Public Personnel Management, Vol 12 No.1.

Hoskisson R.E and Hitt M.A. (1994). Retrenchment: How to tame the diversified firm, New York, Oxford University Press.

Janse. J.V. (2002). “How to Retrench Staff”: My Own Business (www.google.com).

Karasek, R.A. \& Theorell, T. (1990). Stress, productivity and reconstruction and working life: New York: Basic Books.

Karimi . J. W.(2002). The problems experienced by organizations in managing the survivors of downsizing, MBA Project, University of Nairobi.

Kast, F.E., Rosenzweig, J.E. (1985). Organization and Management: A System and Contingency Approach, McGraw-Hill, Singapore.

Lewis. P. (1992). Practical Employment Law-A guide for Human Resource Managers, Blackwell Publishers.

Littler, C.R., (1998). "Downsizing organisations: the dilemmas of change", Human Resources Management Bulletin, CCH Australia Limited, Sydney

Luthans, B.C., Sommer, S.M., (1999). "The impact of downsizing on.workplace attitudes", Group and Organization Management, 24 (1), 46-70 doi: 10.1177/1059601199241004, http://dx.doi.org/10.1177/1059601199241004

Macky, K., (2004). "Organisational downsizing and redundancies: The New Zealand workers' experience". New Zealand Journal of Employment Relations, 29 (1), 63-87

Makawatsakul N.and Kleiner B. H. (2003). "The effect of downsizing on morale and attrition”, Management Research News, Vol 26, No. 2/3/4. doi: 10.1108/01409170310783998

Mentzer, M.S. (1996), "Corporate downsizing and profitability in Canada", Canadian Journal of Administrative Sciences, Vol. 13 pp.237-50. doi:10.1111/j.1936-4490.1996.tb00734.x, http://dx.doi.org/10.1111/j.1936-4490.1996.tb00734.x

Mishra A. K. and Spreitzer G. M.(1998). "Explaining how survivors respond to retrenchment: The roles of trust, empowerment, justice and work redesign". Academy of Journal of the international personnel management association, Management Review,23(3), 567-588.

Mishra, A.N., Mishra, K.E., (1994). "The role of mutual trust in effective downsizing strategies", Human Resource Management Journal, 33, 261-279 doi: 10.1002/hrm.3930330207, http://dx.doi.org/10.1002/hrm.3930330207

Moi. D. J. (2002). The nature of responses of survivors to downsizing, MBA Project, University of Nairobi.

Mwangi .E. N. (2002). A survey of factors that influence the attitudes of survivors of downsizing towards management and job security in the banking sector.

Noer D. M. (1995). Healing the wounds. Overcoming the trauma of staff retrenchment and revitalizing retrenched organizations. Jossey-Bass Inc. Publishers.

Noer. D. (1993). Healing the wounds: Overcoming the trauma of layoffs and revitalizing retrenched organizations, San Fransisco: Jessey-Bass.

Palmer, I., Kabanoff, B., et al., (1997). "Managerial accounts of downsizing”, Journal of Organizational Behavior, 18, 623-640, doi:10.1002/(SICI)1099-1379(199711)18:1+<623::AID-JOB909>3.0.CO;2-T, http://dx.doi.org/10.1002/(SICI)1099-1379(199711)18:1+\%3C623::AID-JOB909\%3E3.0.CO;2-T

Richard L. K., Bransted E., and Milan M. (1996). From retrenchment to recovery, Davis-black publishing. 
Ryan, L., Macky K.A., (1998). "Downsizing organizations: Uses, outcomes and strategies", Asia Pacific Journal of Human Resources, 36 (2), 29-45 doi:10.1177/103841119803600204, http://dx.doi.org/10.1177/103841119803600204

Sahdev, K., (2003). "Survivors' reactions to downsizing: The importance of contextual factors", Human Resource Management Journal, 13 (4), 56-74 doi: 10.1111/j.1748-8583.2003.tb00105.x, http://dx.doi.org/10.1111/j.1748-8583.2003.tb00105.x

Sahdev. K. ,Vinnicombe. S. and Tyson. S.(1999). "Retrenchment and the Changing Role of Human Resource", The International Journal of Human Resource Management 10(5).

Sparrow P. and Marchington M. (1998), Human Resource Management. The new agenda, London, Pitman Publishing.

Tylezak. L. (1991). Retrenchment without disaster, London: Kogan page.

Ulrich, D. (1998), “A new mandate for human resources”, Havard Business Review, Jan-Feb, 124-135.

Weitzel W. and Jonsson E (1989). "Decline in organizations: A literature integration and extension", Administrative Science Quarterly, 34: 91-109. http://www.jstor.org/stable/2392987 doi:10.2307/2392987, http://dx.doi.org/10.2307/2392987

Wetlaufer S. (1998), “After the layoffs, what next?”, Havard Business Review, pg 25-42.

Table 1. Predictable reactions to the emotional impact of job termination

\begin{tabular}{|c|c|}
\hline Emotional Reaction & Observable Behaviour \\
\hline Shock & Silence \\
Immobilization & Blank look, tears \\
Disbelief & Shocked questioning \\
Denial & Debate, argument \\
Anger & Automatic verbal outburst \\
Bargaining & Pleading \\
Frustration & Depression \\
Grieving & Opening up/looking ahead \\
Resolution & Letting go \\
\hline
\end{tabular}

Source: Richard L. K., Elizabeth B., and Milan M. (1996). From retrenchment to recovery, Davis-black publishing, page 234.

Table2. Selection assessment methods

\begin{tabular}{|c|l|}
\hline Selection method & \multicolumn{1}{c|}{ Comments } \\
\hline "Last on, first off" & $\begin{array}{l}\text { Although this seems fair, it ignores the issue of promising or good quality } \\
\text { employees. It has also been rejected by some tribunals as a suitable basis for } \\
\text { selecting candidates for redundancy. }\end{array}$ \\
\hline "First on, first off" & $\begin{array}{l}\text { This removes older employees and can create more opportunity for those } \\
\text { that remain, but reduce the level of experience and may undermine loyalty. }\end{array}$ \\
\hline Standard of job performance & $\begin{array}{l}\text { This can remove poor performing employees, as identified by a performance } \\
\text { appraisal system. This is useful, however many performance review systems } \\
\text { are flawed. Further, if this is the basis used, employees must provide } \\
\text { "procedural fairness" as if it were a dismissal, giving the employee feedback } \\
\text { and opportunity to improve. }\end{array}$ \\
\hline Future potential & $\begin{array}{l}\text { Those with the least potential are retrenched first. This would have to rely on } \\
\text { some measure of potential, such as performance review. Because of this, it } \\
\text { too would require "procedural fairness". It also requires careful human } \\
\text { resources planning to ensure that future needs will be met. }\end{array}$ \\
\hline Voluntary & $\begin{array}{l}\text { Employees who would like to be made redundant are given the opportunity } \\
\text { to come forward. This can result in many of the best employees leaving, as } \\
\text { they are more confident of picking up jobs elsewhere. }\end{array}$ \\
\hline
\end{tabular}


Table 3. Distribution of respondents by gender

\begin{tabular}{|c|c|c|}
\hline Gender & Frequency & Percentage \\
\hline Male & 15 & 75 \\
\hline Female & 5 & 25 \\
\hline Total & $\mathbf{2 0}$ & $\mathbf{1 0 0}$ \\
\hline
\end{tabular}

Table 4. Position of respondents in the banks

\begin{tabular}{|c|c|c|}
\hline Position of respondents & Frequency & Percentage \\
\hline HR Manager & 12 & 60 \\
\hline HR Advisor & 1 & 5 \\
\hline Assistant HR & 4 & 20 \\
\hline HR Dev. Manager & 3 & 15 \\
\hline Total & 20 & 100 \\
\hline
\end{tabular}

Table 5. Title given to head of HR department in the banking industry

\begin{tabular}{|c|c|c|}
\hline Title for head of HR & Frequency & Percentage \\
\hline Group HR Director & 4 & 20 \\
\hline HR Manager & 11 & 55 \\
\hline Chief HR Manager & 4 & 20 \\
\hline General Manager & 1 & 5 \\
\hline Total & 20 & 100 \\
\hline
\end{tabular}

Table 6. Distribution of respondents' experience in years

\begin{tabular}{|c|c|c|}
\hline Experience in years & Frequency & Percentage \\
\hline $0-8$ years & 10 & 50 \\
\hline 9-16 years & 7 & 35 \\
\hline 17-24 years & 2 & 10 \\
\hline Over 24 years & 1 & 5 \\
\hline Total & $\mathbf{2 0}$ & $\mathbf{1 0 0}$ \\
\hline
\end{tabular}

Table 7. Distribution of banks by age

\begin{tabular}{|c|c|c|}
\hline Period of existence in years & Frequency & Percentage \\
\hline Less than 10 years & 2 & 10 \\
\hline $11-20$ years & 7 & 35 \\
\hline 21-30 years & 1 & 5 \\
\hline Over 30 years & 10 & 50 \\
\hline Total & $\mathbf{2 0}$ & $\mathbf{1 0 0}$ \\
\hline
\end{tabular}

Table 8 . Number of employees in the various banks

\begin{tabular}{|c|c|c|}
\hline No. of employees & Frequency & Percentage \\
\hline $1-500$ & 15 & 75 \\
\hline $501-1000$ & 1 & 5 \\
\hline $1001-1500$ & 1 & 5 \\
\hline Over 1500 & 3 & 15 \\
\hline Total & $\mathbf{2 0}$ & $\mathbf{1 0 0}$ \\
\hline
\end{tabular}


Table 9. Distribution of banks by ownership

\begin{tabular}{|c|c|c|}
\hline Ownership & Frequency & Percentage \\
\hline Locally owned & 12 & 60 \\
\hline Foreign owned & 4 & 20 \\
\hline Joint venture & 4 & 20 \\
\hline Total & $\mathbf{2 0}$ & $\mathbf{1 0 0}$ \\
\hline
\end{tabular}

Table 10. Proportion of ownership of joint venture

\begin{tabular}{|c|c|c|}
\hline Proportion of ownership & Frequency & Percentage \\
\hline Largely foreign owned & 3 & 60 \\
\hline Largely locally owned & 2 & 40 \\
\hline Total & $\mathbf{5}$ & $\mathbf{1 0 0}$ \\
\hline
\end{tabular}

Table 11. Distribution of banks by size

\begin{tabular}{|c|c|c|}
\hline Size of banks & Frequency & Percentage \\
\hline Large & 11 & 55 \\
\hline Medium & 5 & 25 \\
\hline Small & 4 & 20 \\
\hline Total & $\mathbf{2 0}$ & $\mathbf{1 0 0}$ \\
\hline
\end{tabular}

Table 12. Number of banks with retrenchment policy

\begin{tabular}{|c|c|c|}
\hline Retrenchment policy & Frequency & Percentage \\
\hline Yes & 13 & 65 \\
\hline No & 7 & 35 \\
\hline Total & $\mathbf{2 0}$ & $\mathbf{1 0 0}$ \\
\hline
\end{tabular}

Table 13. Number of times retrenchment has been done

\begin{tabular}{|c|c|c|}
\hline Number of times retrenched & Frequency & Percentage \\
\hline Once & 12 & 60 \\
\hline Twice & 5 & 25 \\
\hline Over 3 times & 3 & 15 \\
\hline Total & $\mathbf{2 0}$ & $\mathbf{1 0 0}$ \\
\hline
\end{tabular}

Table 14. Provision of outplacement services by banks

\begin{tabular}{|c|c|c|}
\hline Outplacement services & Frequency & Percentage \\
\hline Yes & 9 & 45 \\
\hline No & 11 & 55 \\
\hline Total & $\mathbf{2 0}$ & $\mathbf{1 0 0}$ \\
\hline
\end{tabular}

Table 15. Performance appraisal systems

\begin{tabular}{|c|c|c|}
\hline Performance appraisal system & Frequency & Frequency \\
\hline Yes & 20 & 100 \\
\hline No & - & - \\
\hline Total & $\mathbf{2 0}$ & $\mathbf{1 0 0}$ \\
\hline
\end{tabular}


Table 16. Extent of use of Last in-First out (LIFO) as a retrenchment criterion

\begin{tabular}{|c|c|c|}
\hline Response & Frequency & Percentage \\
\hline To a very great extent & 1 & 5 \\
To a great extent & 2 & 10 \\
To a moderate extent & 7 & 35 \\
To a less extent & 5 & 25 \\
Not at all & 5 & 25 \\
\hline Total & $\mathbf{2 0}$ & $\mathbf{1 0 0}$ \\
\hline
\end{tabular}

Table 17. Extent of use of employees' individual productivity as a retrenchment criterion

\begin{tabular}{|c|c|c|}
\hline Response & Frequency & Percentage \\
\hline To a very great extent & 12 & 60 \\
To a great extent & 7 & 35 \\
To a moderate extent & 1 & 5 \\
To a less extent & - & - \\
Not at all & - & - \\
\hline Total & $\mathbf{2 0}$ & $\mathbf{1 0 0}$ \\
\hline
\end{tabular}

Table 18. Extent of use of misconduct as a retrenchment criterion

\begin{tabular}{|c|c|c|}
\hline Response & Frequency & Percentage \\
\hline To a very great extent & 8 & 40 \\
To a great extent & 4 & 20 \\
To a moderate extent & 4 & 20 \\
To a less extent & 1 & 5 \\
Not at all & 3 & 15 \\
\hline Total & $\mathbf{2 0}$ & $\mathbf{1 0 0}$ \\
\hline
\end{tabular}

Table 19. Extent of use of incapability as a retrenchment criterion

\begin{tabular}{|c|c|c|}
\hline Response & Frequency & Percentage \\
\hline To a very great extent & 5 & 25 \\
To a great extent & 3 & 15 \\
To a moderate extent & 3 & 15 \\
To a less extent & 4 & 20 \\
Not at all & 5 & 25 \\
\hline Total & $\mathbf{2 0}$ & $\mathbf{1 0 0}$ \\
\hline
\end{tabular}

Table 20. Extent of use of early retirement programs as a retrenchment criterion

\begin{tabular}{|c|c|c|}
\hline Response & Frequency & Percentage \\
\hline To a very great extent & 3 & 15 \\
To a great extent & 4 & 20 \\
To a moderate extent & 5 & 25 \\
To a less extent & 5 & 25 \\
Not at all & 3 & 15 \\
\hline Total & $\mathbf{2 0}$ & $\mathbf{1 0 0}$ \\
\hline
\end{tabular}


Table 21. Association between Last in-First out (LIFO) and age of a bank

\begin{tabular}{|l|l|l|l|l|l|}
\hline & \multicolumn{5}{|c|}{ Years of operation } \\
\hline \multicolumn{1}{|c|}{ Extent of use } & Less than 10 years & $11-20$ years & $21-30$ years & Over 30 years & Total \\
\hline To a very great extent & & & & 1 & 1 \\
To a great extent & & 1 & 1 & & 2 \\
To a moderate extent & & 3 & & 4 & 7 \\
To a less extent & 1 & 2 & 1 & 2 & 5 \\
Not at all & 1 & 6 & 2 & 3 & 5 \\
Total & 2 & & 10 & 20 \\
\hline
\end{tabular}

Table 22. Association between employees' individual productivity and age of a bank

\begin{tabular}{|l|c|c|c|c|c|}
\hline & \multicolumn{5}{|c|}{ Years of operation } \\
\hline \multicolumn{1}{|c|}{ Extent of use } & Less than 10 years & $11-20$ years & $21-30$ years & Over 30 years & Total \\
\hline To a very great extent & 1 & 3 & 2 & 7 & 12 \\
To a great extent & 1 & 3 & & 3 & 7 \\
To a moderate extent & 2 & & & & 1 \\
Total & 6 & 2 & 10 & 20 \\
\hline
\end{tabular}

Table 23. Association between misconduct as a criterion and age of a bank

\begin{tabular}{|l|c|c|c|c|c|}
\hline & \multicolumn{5}{|c|}{ Years of operation } \\
\hline \multicolumn{1}{|c|}{ Extent of use } & Less than 10 years & $11-20$ years & $21-30$ years & Over 30 years & Total \\
\hline To a very great extent & 1 & 2 & 1 & 4 & 8 \\
To a great extent & & 3 & & 1 & 4 \\
To a moderate extent & 1 & 1 & 1 & 1 & 4 \\
To a less extent & & & & 1 & 1 \\
Not at all & 2 & 6 & 2 & 3 & 3 \\
Total & & & & 10 & 20 \\
\hline
\end{tabular}

Table 24. Association between incapability as a criterion and age of a bank

\begin{tabular}{|l|c|c|c|c|c|}
\hline & \multicolumn{4}{|c|}{ Years of operation } \\
\hline \multicolumn{1}{|c|}{ Extent of use } & Less than 10 years & $11-20$ years & $21-30$ years & Over 30 years & Total \\
\hline To a very great extent & 1 & & & 5 & 5 \\
To a great extent & 1 & 3 & 1 & 3 \\
To a moderate extent & & 2 & 1 & 1 & 3 \\
To a less extent & 1 & 1 & & 3 & 4 \\
Not at all & 2 & 6 & 2 & 10 & 20 \\
Total & & 2 & & \\
\hline
\end{tabular}

Table 25.Association between early retirement programs and age of a bank

\begin{tabular}{|l|c|c|c|c|c|}
\hline \multicolumn{1}{|c|}{ Extent of use } & \multicolumn{4}{|c|}{ Years of operation } \\
\hline To a very great extent & Less than 10 years & $11-20$ years & $21-30$ years & Over 30 years & Total \\
To a great extent & 1 & 1 & 1 & 1 & 3 \\
To a moderate extent & & & & 3 & 4 \\
To a less extent & & 2 & 1 & 2 & 5 \\
Not at all & 1 & 3 & & 2 & 5 \\
Total & 2 & 6 & 2 & 2 & 3 \\
\hline
\end{tabular}


Table 26. Association between Last in-First out (LIFO) and size of a bank

\begin{tabular}{|l|c|c|c|c|}
\hline \multicolumn{1}{|c|}{ Extent of use } & \multicolumn{4}{|c|}{ Size of a bank } \\
\hline To a very great extent & & 1 & & 1 \\
To a great extent & & 1 & 1 & 2 \\
To a moderate extent & 4 & 1 & 2 & 7 \\
To a less extent & 2 & 1 & 2 & 5 \\
Not at all & 4 & & 1 & 5 \\
Total & 10 & 4 & 6 & 20 \\
\hline
\end{tabular}

Table 27. Association between employees' individual productivity and size of the bank

\begin{tabular}{|l|c|c|c|c|}
\hline & \multicolumn{4}{|c|}{ Size of a bank } \\
\hline \multicolumn{1}{|c|}{ Extent of use } & Large & Medium & Small & Total \\
\hline To a very great extent & 7 & 3 & 2 & 12 \\
To a great extent & 3 & 1 & 3 & 7 \\
To a moderate extent & & & 1 & 1 \\
Total & 10 & 4 & 6 & 20 \\
\hline
\end{tabular}

Table 28. Association between Misconduct as a criterion and size of a bank

\begin{tabular}{|l|c|c|c|c|}
\hline \multicolumn{1}{|c|}{ Extent of use } & \multicolumn{4}{|c|}{ Size of a bank } \\
\hline To a very great extent & 3 & 2 & 3 & 8 \\
To a great extent & 1 & 2 & 1 & 4 \\
To a moderate extent & 2 & & 2 & 4 \\
To a less extent & 1 & & & 1 \\
Not at all & 3 & & & 3 \\
Total & 10 & 4 & 6 & 20 \\
\hline
\end{tabular}

Table 29. Association between incapability as a criterion

\begin{tabular}{|l|c|c|c|c|}
\hline \multicolumn{1}{|c|}{ Extent of use } & \multicolumn{4}{|c|}{ Size of a bank } \\
\hline To a very great extent & 4 & 1 & & 5 \\
To a great extent & 1 & 1 & 1 & 3 \\
To a moderate extent & & & 3 & 3 \\
To a less extent & 2 & 2 & & 4 \\
Not at all & 3 & & 2 & 5 \\
Total & 10 & 4 & 6 & 20 \\
\hline
\end{tabular}

Table 30. Association between early retirement programs and size of a bank

\begin{tabular}{|l|c|c|c|c|}
\hline \multicolumn{1}{|c|}{ Extent of use } & \multicolumn{4}{|c|}{ Size of a bank } \\
\hline To a very great extent & 1 & 1 & 1 & 3 \\
To a great extent & 3 & & 1 & 4 \\
To a moderate extent & 3 & 1 & 1 & 5 \\
To a less extent & 1 & 2 & 2 & 5 \\
Not at all & 2 & & 1 & 3 \\
Total & 10 & 4 & 6 & 20 \\
\hline
\end{tabular}


Table 31. Association between Last in-Last out (LIFO) and ownership of a bank

\begin{tabular}{|l|c|c|c|c|}
\hline & \multicolumn{4}{|c|}{ Ownership of a bank } \\
\hline \multicolumn{1}{|c|}{ Extent of use } & Locally owned & Foreign owned & Joint venture & Total \\
\hline To a very great extent & & 1 & & 1 \\
To a great extent & 1 & 1 & & 2 \\
To a moderate extent & 4 & 2 & 1 & 7 \\
To a less extent & 3 & 1 & 1 & 5 \\
Not at all & 2 & & 3 & 5 \\
Total & 10 & 5 & 5 & 20 \\
\hline
\end{tabular}

Table 32. Association between employees individual productivity and ownership of a bank

\begin{tabular}{|l|c|c|c|c|}
\hline & \multicolumn{4}{|c|}{ Ownership of a bank } \\
\hline \multicolumn{1}{|c|}{ Extent of use } & Locally owned & Foreign owned & Joint ventures & Total \\
\hline To a very great extent & 6 & 4 & 2 & 12 \\
To a great extent & 4 & 1 & 2 & 7 \\
To a moderate extent & & & 1 & 1 \\
Total & 10 & 5 & 5 & 20 \\
\hline
\end{tabular}

Table 33. Association between Misconduct as a criterion and ownership of a bank

\begin{tabular}{|l|c|c|c|c|}
\hline & \multicolumn{4}{|c|}{ Ownership of a bank } \\
\hline \multicolumn{1}{|c|}{ Extent of use } & Locally owned & Foreign owned & Joint venture & Total \\
\hline To a very great extent & 4 & 3 & 1 & 8 \\
To a great extent & 3 & & 1 & 4 \\
To a moderate extent & 3 & 1 & & 4 \\
To a less extent & & & 2 & 1 \\
Not at all & 10 & 5 & 5 & 3 \\
Total & & 5 & \\
\hline
\end{tabular}

Table 34. Association between incapability as a criterion and ownership of a bank

\begin{tabular}{|l|c|c|c|c|}
\hline & \multicolumn{4}{|c|}{ Ownership of a bank } \\
\hline \multicolumn{1}{|c|}{ Extent of use } & Locally owned & Foreign owned & Joint venture & Total \\
\hline To a very great extent & 2 & 1 & 2 & 5 \\
To a great extent & & 3 & & 3 \\
To a moderate extent & 3 & & & 3 \\
To a less extent & 3 & 1 & 2 & 4 \\
Not at all & 2 & 5 & 5 & 5 \\
Total & 10 & & & 20 \\
\hline
\end{tabular}

Table 35. Association between early retirement programs and ownership of a bank

\begin{tabular}{|l|c|c|c|c|}
\hline \multicolumn{1}{|c|}{ Extent of use } & \multicolumn{4}{|c|}{ Ownership of a bank } \\
\hline To a very great extent & 2 & 1 & & Total \\
To a great extent & & 2 & 2 & 4 \\
To a moderate extent & 5 & 1 & 1 & 5 \\
To a less extent & 3 & 1 & 2 & 5 \\
Not at all & 10 & 5 & 5 & 3 \\
Total & & & & 20 \\
\hline
\end{tabular}




\section{Appendix}

\section{Appendix 1. Questionnaire}

Please answer the following questions by ticking $[\downarrow]$ in the appropriate bracket or by giving the necessary details in the spaces provided.

Section A

Part I: Respondent Profile

1. What is your gender?

2. Title or position of the respondent in the organization.

[ ] Male [ ] Female

3 . What is the title given to the head of Human Resource department in your organization?

4. How long have you been with this organization? [ ] 0-8 years [ ] 9-16 years [ ] $17-24$ years [ ] Over 24 years

Part II: Organization Data

5. Name of the organization

6. For how long has the organization been in existence? [ ] Less than 10 years [ ] 11-20 years [ ] 21-30 years [ ] Over 30 years

7. How many employees are in the organization? [ ]1-500 [ ] 501-1000 [ ]1001-1500

[ ] Over 1500

8. How would you classify your organization in regard to ownership? specify

$$
\text { [ ] Locally owned [ ]Foreign owned [ ]Combination of local and foreign }
$$

Other [ ] Please

9. Incase your organization is a joint venture between foreign and local investors, what is the proportion of ownership?

10. How would you rate your bank according to the value of assets owned?

$$
\text { [ ] Largely foreign owned [ ] Largely locally owned [ ] Equally owned }
$$
[ ] Assets over Ksh. $5000 \mathrm{M} \quad$ [ ] Assets between Ksh. $3000 \mathrm{M}$ and
11. Does your organization have retrenchment policy?

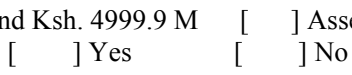

12. How many times have you carried out retrenchment over the last 5 years?

13. How many employees were left after the last retrenchment?

14. Do you provide counseling and other outplacement services to the leavers?

If yes, what do they include?

Section B: Questions Specific to Criteria for Retrenchment

15. Staff retrenchment occur by seniority, on the last-in first-out basis.

[ ] To a very great extent

[ ] To a great extent

[ ] To a moderate extent

[ ] To a less extent

[ ] Not at all

16. To what extent did you consider employees' individual productivity in the retrenchment decision?

[ ] To a very great extent

[ ] To a great extent

[ ] To a moderate extent

[ ] To a less extent

[ ] Not at all

17. To what extent is misconduct considered as a criterion for retrenchment?

[ ] To a very great extent

[ ] To a great extent

[ ] To a moderate extent

[ ] To a less extent

[ ] Not at all

18. Incapability is used as a criterion for retrenchment.

[ ] To a very great extent

[ ] To a great extent

[ ] To a moderate extent

[ ] To a less extent

[ ] Not at all

19. Are early retirement programs used as a criterion for retrenchment?

[ ] To a very great extent

[ ] To a great extent

[ ] To a moderate extent

[ ] To a less extent

[ ] Not at all

20. How is seniority defined?

[ ] Age

[ ] Length of service with the organization

Other, please specify

21. Is there a performance appraisal system in place?

[ ] Yes

[ ] No

If no, how is performance measured?

22. What behavior does the organization consider as misconduct?

23. What factors characterize incapability?

[ ] Lack of skills

[ ] Lack of aptitude 
[ ] Ill-health

[ ]Any physical and mental qualities

Other, please specify

24 . Does the organization have any early retirement programs?

[ ] Yes

[ ] No

25. What other criteria does the bank use as a basis for retrenchment?

26. Who is involved in the selection of those to be retrenched?

[ ]The organization senior management

[ External consultants

[ ] Combination of both senior management and external consultants

Other, please specify

27. When did your organization lastly retrench and which criteria did it use?

\section{Appendix 2. List of commercial banks in Kenya}

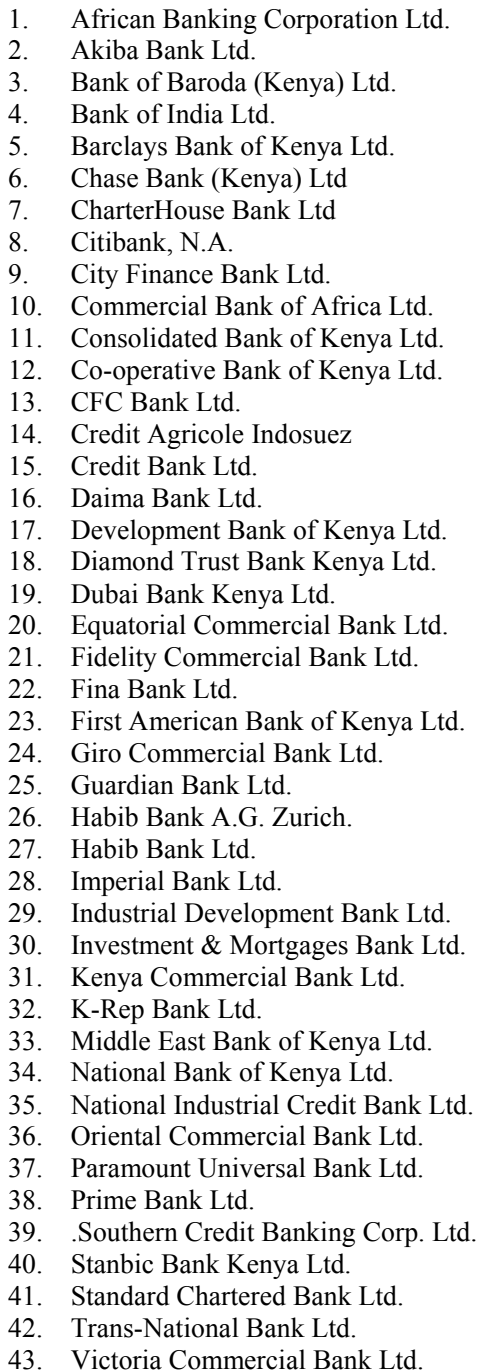

